\title{
The slip-rate along the northern Itoigawa-Shizuoka tectonic line active fault system, central Japan
}

\author{
Nobuhisa Matsuta ${ }^{1}$, Yasutaka Ikeda ${ }^{2}$, and Hiroshi Sato ${ }^{1}$ \\ ${ }^{1}$ Earthquake Research Institute, University of Tokyo, 1-1-1 Yayoi, Bunkyo-ku, Tokyo 113-0032, Japan \\ ${ }^{2}$ Department of Earth and Planetary Science, University of Tokyo, Tokyo 113-0033, Japan
}

(Received May 31, 2004; Revised November 22, 2004; Accepted December 6, 2004)

\begin{abstract}
The slip-rates on the northern extent of Itoigawa-Shizuoka tectonic line (ISTL) are estimated based on seismic reflection profiles, drill core data and analysis of tectonic geomorphology. The ISTL is a major tectonic line that passes through the Honshu Island of Japan, and its northern and central segments form an active fault system characterized by high slip-rates. In the Kamishiro basin, near the northern end of the ISTL active fault system, the rate of net slip is estimated to be 4.4-5.4 m/kyr over the last $28 \mathrm{ka}$, with a vertical-separation-rate of 2.2-2.7 $\mathrm{m} / \mathrm{kyr}$. In the Omachi area, south of the Kamishiro basin, the Quaternary slip-rate is estimated to be at least 2.9 $\mathrm{m} / \mathrm{kyr}$ based on the balanced cross-section derived from reflection profiles and surface geology. The dip angle of $30^{\circ}$ determined from the Omachi seismic profile suggests a vertical-separation-rate of at least $1.5 \mathrm{~m} / \mathrm{kyr}$. Based on compiled evidence from the available geomorphological and paleo-seismological data, vertical-slip-rates of $1.0-2.9 \mathrm{~m} / \mathrm{kyr}$ are inferred for the region between Hakuba and Toyoshina over the past $3 \mathrm{ka}$. The northern ISTL exhibits dip-slip-rate of at least $2.9 \mathrm{~m} / \mathrm{kyr}$, with a constant average slip-rate of $2.0-5.8 \mathrm{~m} / \mathrm{kyr}$ since the Early Quaternary. A paleoseismological data and long-term slip-rate along the northern ISTL has potential for a large earthquake.
\end{abstract}

Key words: Northern Itoigawa-Shizuoka tectonic line, active fault, tectonic geomorphology, slip-rate.

\section{Introduction}

The active fault system of the Itoigawa-Shizuoka tectonic line (ISTL) in central Japan exhibits the one of the highest active-rates of any fault system in the Japanese islands. Slip-rates on the northern extent of the ISTL have been estimated using Late Quaternary offset terraces, yielding sliprates on the order of several m/kyr (Oguchi, 1990; Okumura, 2001; Matsuta et al., 2001). Paleoseismological research of the ISTL active fault system has indicated that the averaged recurrence interval of surface displacement on the northern ISTL is $1258-1510 \mathrm{yr}$, with the most recent seismic event occurring in 841 AD (Okumura, 2001). Thus, there is a high imminent potential for a large earthquake on this fault system considering the characteristic earthquake model proposed by the Headquarters for Earthquake Research Promotion (1996). Accurate determination of the slip-rates of active faults is therefore essential for developing a quantitative understanding of crustal deformation and for seismic hazard assessment (e.g., McCalpin, 1996).

Two geometrical models have been proposed for the northern extent of the ISTL active fault system: Takeuchi and Abe (1999) presented a high-angle fault model based on the hypocentral distribution and focal mechanism, while Sato et al. (2004) have derived a thrust model based on the structural geology and a seismic reflection survey. To settle the question needs to determine whether the deformation

Copy right(c) The Society of Geomagnetism and Earth, Planetary and Space Sciences (SGEPSS); The Seismological Society of Japan; The Volcanological Society of Japan; The Geodetic Society of Japan; The Japanese Society for Planetary Sciences; TERRAPUB. structure has grown, and whether the tectonic setting has changed since the Late Quaternary. Using seismic reflection profiles and drill-hole data, slip-rates of this active fault are estimated quantitatively based on geomorphic and geologic markers of different ages in order to compare long-term and short-term slip-rates.

\section{Geological Setting \\ 2.1 Tectonic setting}

The ISTL is a major fault system that separates southwestern Japan from northeastern Japan (Fig. 1). The northern extent of the ISTL bounds the western side of the northern Fossa Magna sedimentary basin, which was formed as a back-arc rift during the final stage of the opening of the Sea of Japan (Sato et al., 2004). Due to shortening since the Pliocene, normal faults that generated through Miocene rifting have been reactivated as reverse faults, resulting in strong folding and faulting of Miocene rift sediments (e.g., Sato et al., 2004). Active faults and tectonic landforms can be found over about $150 \mathrm{~km}$ of the ISTL, and these are called the ISTL active fault system. The ISTL active fault system can be divided into two distinct segments (Matsuta et al., 2003). The northern segment has east-dipping reverse fault. The vertical-separation-rates obtained from the observed offsets of river terraces and deposits for this northern part are 1-3 m/kyr (Oguchi, 1990; Matsuta et al., 2001). 2.2 The Kamishiro basin

The Kamishiro basin is located on the northern part of the northern ISTL active fault system. The basin is $1.2 \mathrm{~km}$ wide and $3.5 \mathrm{~km}$ long, and is filled with Late Quaternary 

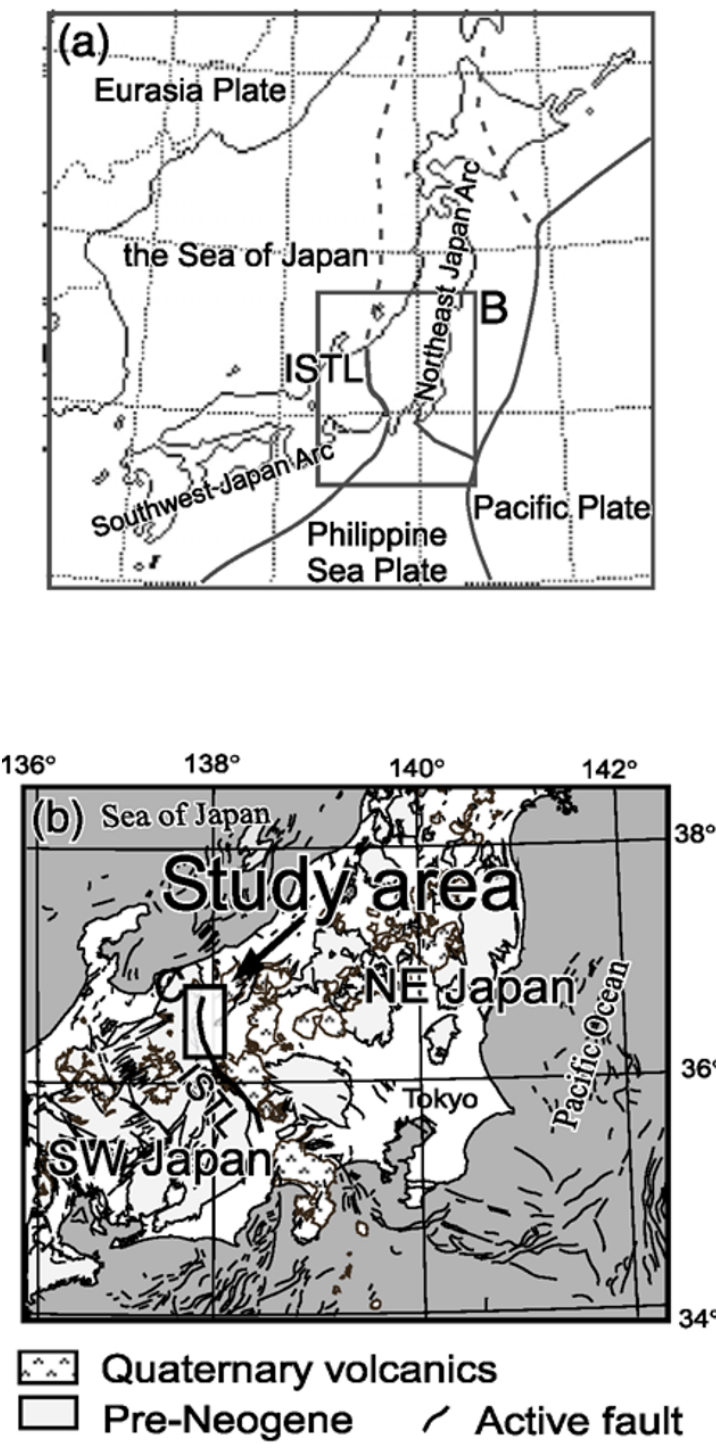

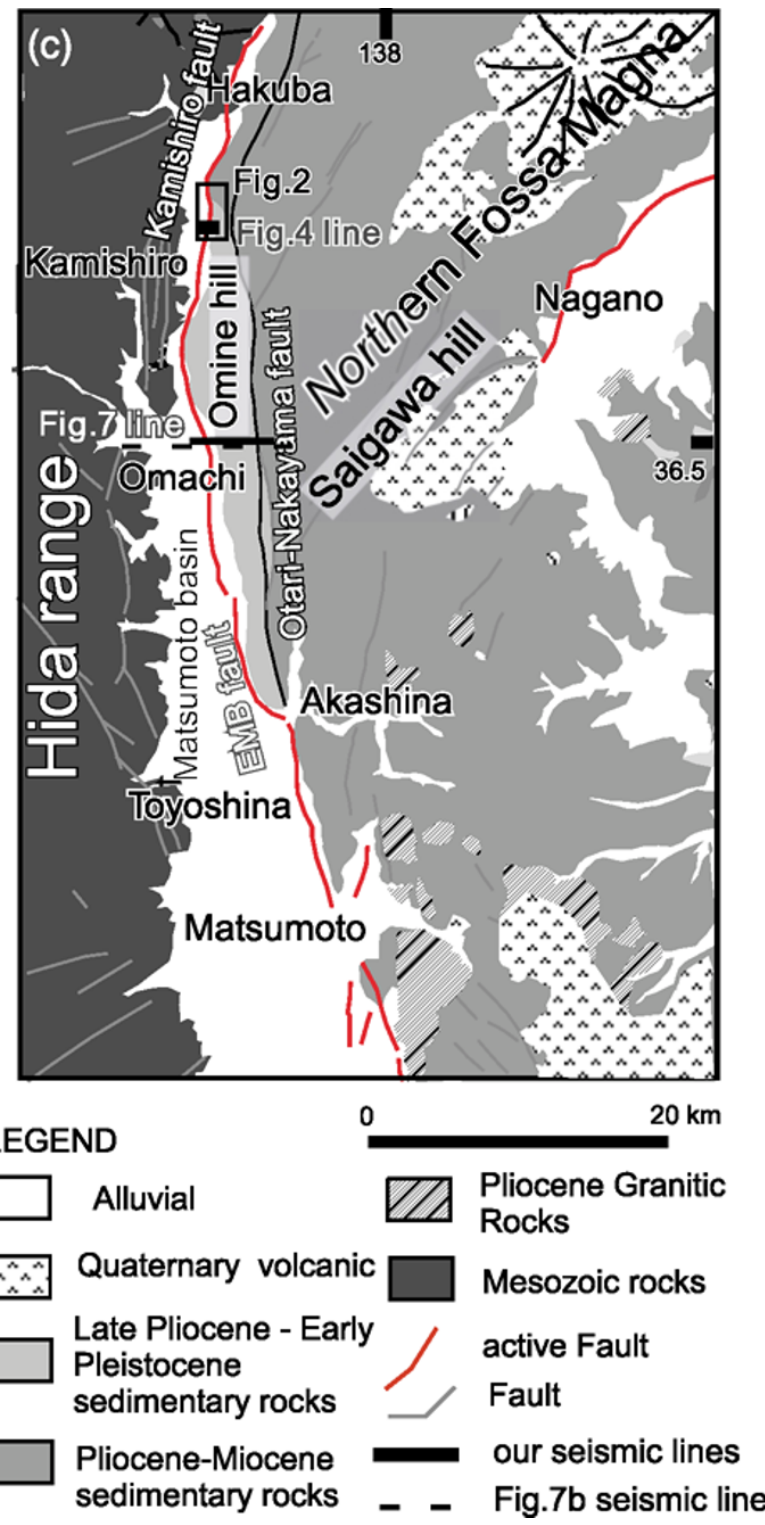

Fig. 1. (a) Tectonic map in and around Japan. Insert B shows the area of Fig. 1(b). (b) Active fault map around the central Honshu (Research group for active faults in Japan, 1991). Insert C shows the area of Fig. 1(c). (c) Geologic setting of northern Fossa Magna and Itoigawa-Shizuoka Tectonic Line, central Japan based on Geological Survey of Japan eds. (1992). Solid black lines indicate active fault (after Ikeda et al., 2002)

lacustrine sediments and fluvial deposits (Shimokawa and Yamazaki, 1987). Based on the distribution of lake within the basin terraces, Kashiwagi (1988) inferred that an ancient Kamishiro Lake was formed by natural damming with fluvial deposits transported from the west as a consequence of climatic change (Fig. 2). The basin was subsequently filled with thick Late Quaternary lacustrine sediments and fluvial deposits, and as such is a suitable site for estimating the average slip-rates through the Late Quaternary.

\subsection{The Omachi area}

Lineations each corresponding to the Eastern Matsumoto basin (EMB) fault and Otari-Nakayama fault are parallel and located south of Omachi. The Omine Hills existing between these two faults, are composed mainly of fluvial gravel supplied from the Hida range in the Pliocene and earliest Quaternary. The fluvial gravel can be correlated to the Omine Formation.

The EMB fault runs along the western edge of the Omine
Hills and displaces Late Quaternary sediments (Shimokawa et al., 1995). Due to erosion, the geomorphic expression of the fault trace is only preserved at several sites, but the displacement of alluvial fans and stream terraces can be clearly seen at those locations (Shimokawa et al., 1995).

The Otari-Nakayama fault separates between Miocene rocks from Pliocene to earliest Quaternary sediments. No geomorphic features indicative of Late Quaternary faulting have been observed along this fault. However, a pumice tuff dated at $1.65 \mathrm{Ma}$ (Nagahashi et al., 2000) is much thicker on the footwall side of the fault than the hangingwall side (Machida et al., 1997). This suggests early Pleistocene faulting. Since the deformed Pleistocene sediments by the ISTL active fault system faulting in Omachi is a simple structure, the amount of slip-induced convergence deformation in the Quaternary can be estimated from balancing method in this area. 
Table 1. Geological column table of a borehole on the high resolution $\mathrm{S}$-wave seismic reflection line.

\begin{tabular}{|c|c|}
\hline Unit 1 & matrix-supported pebble \\
\hline Unit 2 & peaty silt \\
\hline Unit 3 & clast-supprted pebble \\
\hline Unit 4 & sandy silt with peat \\
\hline Unit 5 & matrix-supported pebble \\
\hline Unit 6 & sandy silt with peat \\
\hline Unit 7 & clast-supprted pebble \\
\hline Unit 8 & silty sand with peat \\
\hline Unit 9 & clast-supprted pebble \\
\hline Unit 10 & sandy silt with peat \\
\hline
\end{tabular}

\section{Estimation of Slip-rate}

\subsection{The Kamishiro fault}

The local name of the ISTL active fault system in this basin is the Kamishiro fault. The trace of the Kamishiro fault is highly convoluted this area, suggestive of a lowangle fault with dominantly dip-slip component. On the hanging wall of the fault, three steps of lake terraces have developed along the tectonic geomorphology created as a flexure due to differential uplift by the faulting (e.g., Kashiwagi, 1988). In this basin, the slip-rates during Late Quaternary are estimated to be $1.5-3.4 \mathrm{~m} / \mathrm{kyr}$ based on results of paleoseismological trenching (Okumura, 2001) and drilling (Shimokawa and Yamazaki, 1987; Imaizumi et al., 1997).

3.1.1 S-wave reflection profile in Kamishiro basin To reveal geometry and deformation of the hanging wall of the Kamishiro fault, high-resolution S-wave seismicreflection data were used along a 200-m-long seismic line across the ISTL active fault system (Matsuta et al., 2001). Figure 3 shows the processing flow chart and parameters. The seismic source employed in the survey was a minivibrator truck (T15000 IVI Inc.) with a 14-20 s upsweep from 15 to $100 \mathrm{~Hz}$, coupled with a Gdaps-4 (JGI) recording system. The data were processed by common mid-point (CMP) reflection methods at the University of Tokyo using IXL (MIT) software.

As P-waves arrive earlier than the first break of S-waves, the first break of S-waves was difficult to identify clearly. Although static correction was not applied, residual static correction and velocity analysis were carefully repeated.

The migrated depth-converted section with the geological columnar section obtained from the borehole is shown in Fig. 4. Black represents gravel layers and grey denotes lacustrine layers on drilling data. Almost horizontal reflectors were identified between CMP 10 and CMP 100 on the footwall side. Three strong reflectors correspond to the boundaries between lacustrine sediments and gravel in the drilling core and are found at 23,50 and $57 \mathrm{~m}$ depth.

3.1.2 Borehole data and terraces in the Kamishiro basin A borehole was drilled at the site on the S-wave seismic reflection survey line (Fig. 4). Table 1 shows a stratigraphy of the borehole core. It is shown that gravels

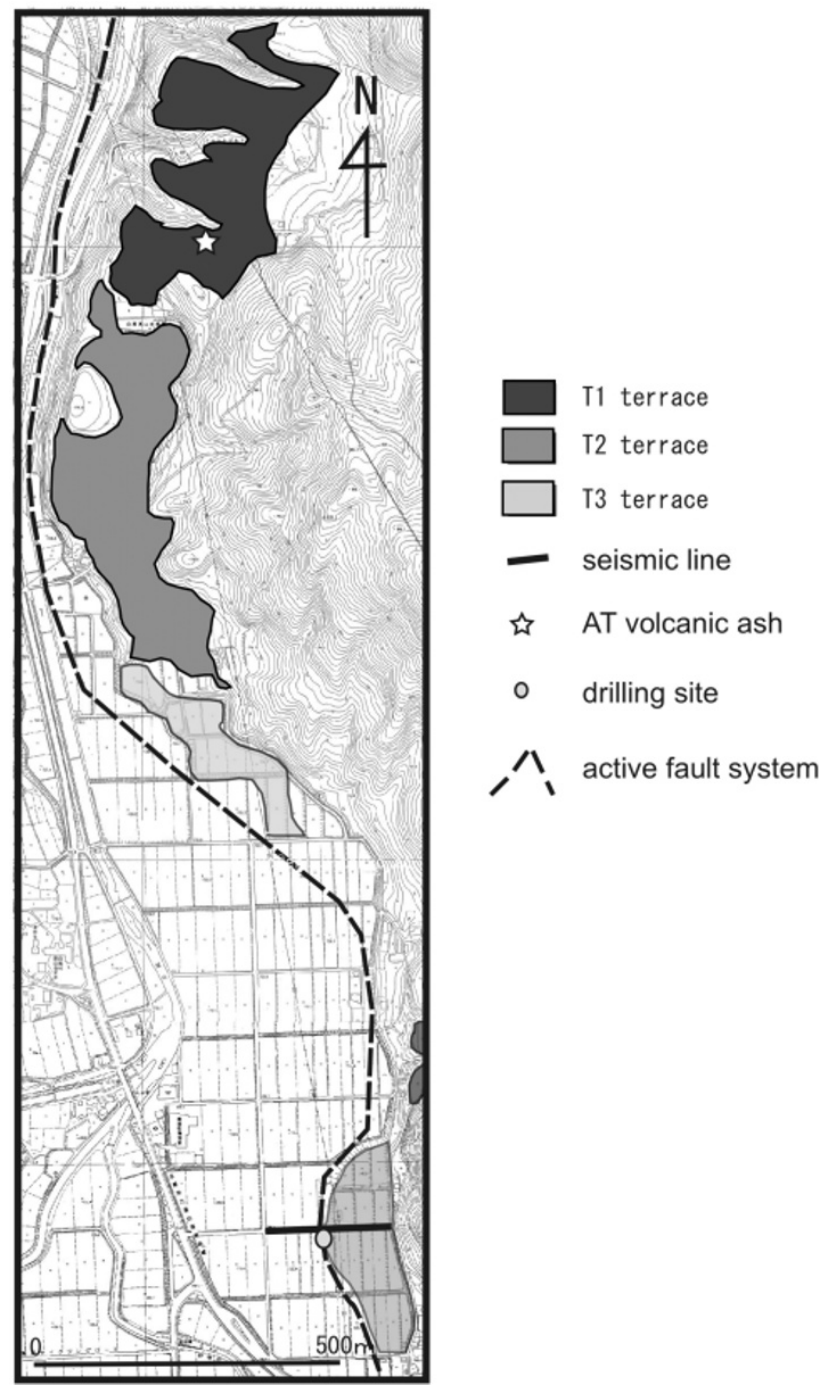

Fig. 2. Distribution of lake terraces in Kamishiro basin. Location of drilling site and S-wave seismic profile are also shown.

are interbeded with lacustrine sediments (Matsuta et al., 2001). These gravels and sediments can be subdivided into 10 units. The lowest unit 10 contains a 5-cm-thick layer of glassy volcanic ash. This ash can be correlated to AT volcanic ash erupted at $28 \mathrm{ka}$ (Machida and Arai, 1992). The altitude of the AT ash found $683.8 \mathrm{~m}$ above sea level. As the drilling core contained a number of peaty layers, dating samples could be collected at a sufficient number of points in the core. Three lake terraces T1, T2, and T3 can be identified in the northeast of the Kamishiro basin. The altitudes of T1, T2, and T3 are 758-760 m, 744-746 m, and $734 \mathrm{~m}$ respectively. In T1 terrace deposits, the AT ash layer occurs within a lacustrine silt at an altitude of $750 \mathrm{~m}$ on the hanging-wall side of the Kamishiro fault.

3.1.3 The slip-rate of the Kamishiro fault As shown in Fig. 5, AT volcanic ash was found in lacustrine sediments on both sides of the Kamishiro fault. The ash layer on the hanging wall side of the fault occurs approximately $66 \mathrm{~m}$ higher than that on its footwall side. As indicated by the interaction of the lacustrine sediments with peat or peaty silt layers, these AT volcanic ash are considered to have deposited in shallows. Assuming that the vol- 


\begin{tabular}{|l|l|}
\hline Length of the seismic line & $200 \mathrm{~m}$ \\
\hline Source & $\begin{array}{l}\text { mini-vibrator } \\
\text { (IVI T15000) }\end{array}$ \\
\hline Sweep frequency & $15-100 \mathrm{~Hz}$ \\
\hline Sweep length & $15 \mathrm{sec}(20 \mathrm{sec})$ \\
\hline No. of sweeps & 5 \\
\hline Shot interval & $2 \mathrm{~m}$ \\
\hline No. of channels & $176 \mathrm{ch}$ \\
\hline Natural frequency & $40 \mathrm{~Hz}$ \\
\hline Recording interval & $1 \mathrm{~m}$ \\
\hline Instruments & GDAPS-4 \\
\hline Sampling interval & $2 \mathrm{~ms}$ \\
\hline Recording length & $3 \mathrm{sec}$ \\
\hline Standard CMP fold & 88 \\
\hline
\end{tabular}

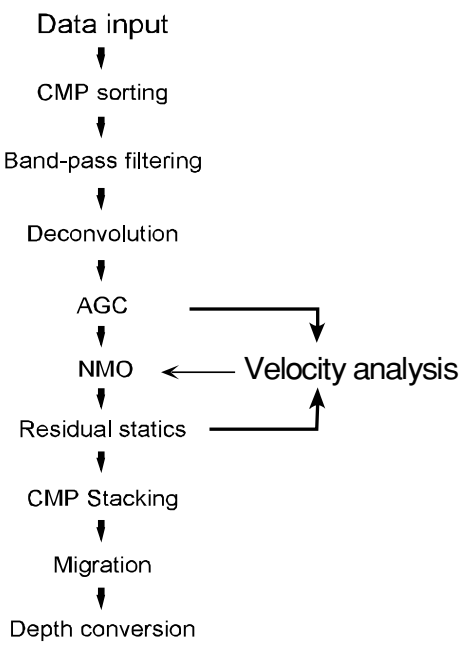

Fig. 3. Data acquisition parameters and flow chart of the seismic data processing for the Kamishiro seismic line.

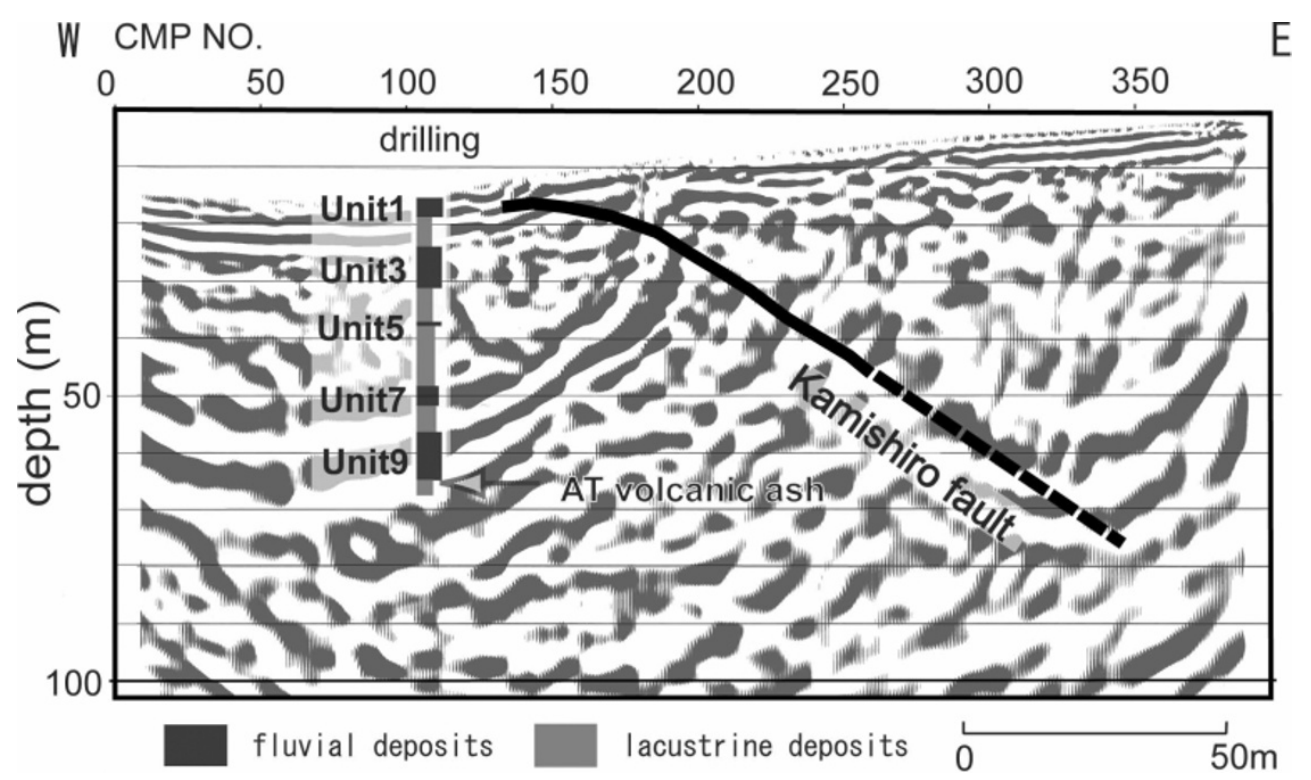

Fig. 4. Interpreted, depth converted, S-wave reflection profile and the geological columnar section of the borehole at Kamishiro.

canic ash has been laid down in shallows horizontally, the vertical-separation-rate is estimated to be $2.4 \mathrm{~m} / \mathrm{kyr}$ over the past $28 \mathrm{ka}$. It is also possible that the gravel units 1, 3, 5,7 , and 9 identified in the drill core were deposited during drainage intervals of the Kamishiro Lake drained. This would suggest vertical-separation-rates on the fault: 2.6$2.7 \mathrm{~m} / \mathrm{kyr}$ for the last $28 \mathrm{ka}, 2.2-2.5 \mathrm{~m} / \mathrm{kyr}$ for the last $14 \mathrm{ka}$, and $2.2-2.4 \mathrm{~m} / \mathrm{kyr}$ for the last $11 \mathrm{ka}$. The overall verticalseparation-rate for the Kamishiro fault is therefore in ranging from 2.4 to $2.7 \mathrm{~m} / \mathrm{kyr}$ at the average over the past $28 \mathrm{ka}$. Given the dip angle of the Kamishiro fault determined by seismic profiling to be approximately $30^{\circ}$, the average net slip-rate on the predominantly dip-slip fault is calculated to be 4.4-5.4 m/kyr. This dip angle of approximately $30^{\circ}$ for the northern ISTL active fault system is also supported by data of Sato et al. (2004) and Ikeda et al. (2004).

\subsection{Eastern Matsumoto basin fault}

3.2.1 Seismic reflection profile along the EMB fault High-resolution seismic-reflection data were acquired along a $6.4 \mathrm{~km}$ transect across the ISTL active fault system (Matsuta et al., 2001). The process flow chart and parameters of the data are shown in Fig. 6. The shallow seismic line overlaps with a part of the deep seismic line investigated by Sato et al. (2004).

The depth converted section is shown in Fig. 7. The relevant dips and strikes of the Omine Formation obtained from the geological map (Kato and Sato, 1983) are marked on the seismic profile for reference. In this seismic section, horizontal reflectors are superior on the west side and many east-dipping reflectors from the Omine Formation can be identified on the east side. The intersection of the seismic line and the EMB fault occurs at about point $\mathrm{C}$, coincident with the boundary between east-dipping reflectors and horizontal reflectors. The down-dip (eastward) extension of the EMB fault is inferred to be located at the base of these reflectors (Fig. 7). The strong east-dipping reflectors are shown between the point $\mathrm{D}$ and the point $\mathrm{E}$. Such as east-dipping reflectors are found near the EMB fault and are 


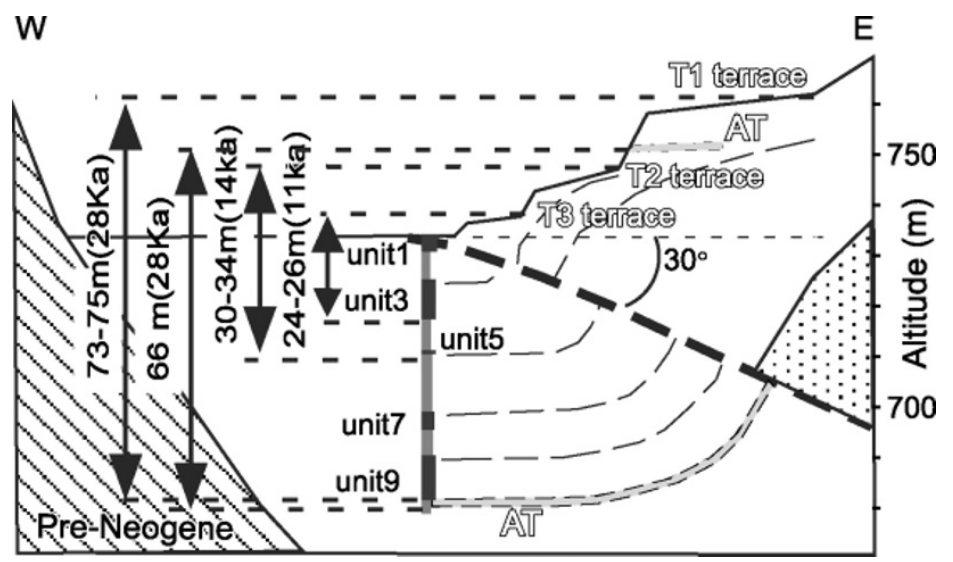

Fig. 5. Schematic geologic cross section across Kamishiro basin, showing the displacement by the Kamishiro fault during late Quaternary.

\begin{tabular}{|l|l|}
\hline Length of the seismic line & $6.4 \mathrm{~km}$ \\
\hline Source & $\begin{array}{l}\text { mini-vibrator } \\
\text { (IVI T15000) }\end{array}$ \\
\hline Sweep frequency & $10-80 \mathrm{~Hz}$ \\
\hline Sweep length & $15 \mathrm{sec}(20 \mathrm{sec})$ \\
\hline No. of sweeps & 5 \\
\hline Shot interval & $10 \mathrm{~m}$ \\
\hline No. of channels & $180 \mathrm{ch}$ \\
\hline Natural frequency & $10 \mathrm{~Hz}$ \\
\hline Recording interval & $10 \mathrm{~m}$ \\
\hline Instruments & GDAPS-4 \\
\hline Sampling interval & $2 \mathrm{~ms}$ \\
\hline Recording length & $3 \mathrm{sec}$ \\
\hline Standard CMP fold & 90 \\
\hline
\end{tabular}

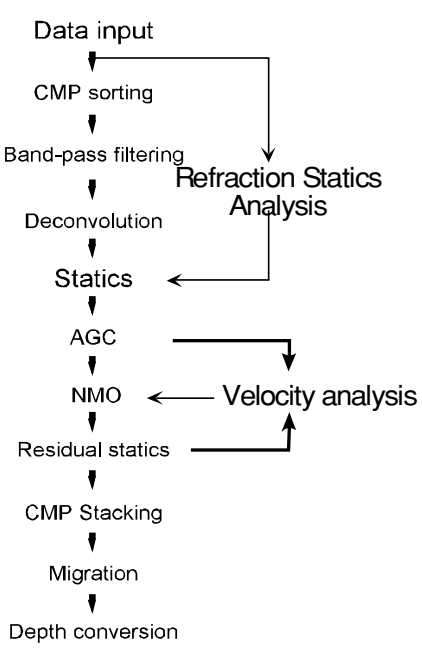

Fig. 6. Data acquisition parameters and flow chart of the seismic data processing for the Kamishiro reflection line.

interpreted to represent an emergent thrust of the EMB fault boundary. The reflectors on the hanging wall correspond to Pleistocene fluvial deposits of the Omine Formation with a characteristic dip of approximately $20^{\circ} \mathrm{E}$, being consistent with the surface geology.

3.2.2 Displacement on the ISTL active fault system in Omachi The Omine Hills are located on the footwall side of the Otari-Nakayama fault, and the amount of shortening imparted by movement on the EMB fault can be estimated from the deformation of the Pliocene-Pleistocene formations. The original dip of the formation is almost horizontal in the hills.

On the seismic profile, the fault dips $26-28^{\circ} \mathrm{E}$, and the fluvial sediments are tilted by $20^{\circ}$ to the east (Fig. 7). Based on the balanced cross-section, the dip angle of the fault changes from $26-28^{\circ} \mathrm{E}$ to $6-8^{\circ} \mathrm{E}$ at a depth of $2.2 \mathrm{~km}$ at the point $\mathrm{B}$ below the point $\mathrm{A}$ in Fig. 7. Although all the reflectors on the hanging wall of the EMB fault have the same dip angle on this profile, the east-dipping reflectors become gentle at a depth of $2.2 \mathrm{~km}$ in the deep reflection profile. Based on the balanced method, it is necessary to slip on the fault plane from point A to point B at approximate 4.7-5.0 $\mathrm{km}$ to grow up the present structure from the original sediments. Since the tip of the EMB fault is eroded, its value is minimum estimate.

3.2.3 The long-term slip-rate of the EMB fault The minimum displacement on the EMB fault is ranging from 4.7 to $5.0 \mathrm{~km}$, as mentioned above. Because the EMB fault did not uplift the Omine Hill at the time of deposition of the 1.65 Ma pumice tuff (Machida et al., 1997), the displacement on the EMB fault may have initiated after deposition of the pumice tuff. This gives a minimum slip-rate of 2.9-3.0 m/kyr. However, as the EMB fault is an emergent thrust and it is impossible to determine the amount of eroded fault front, this slip-rate represents a minimum amount for the fault. The slip estimation depends heavily on the age of faulting on the EMB fault. The Omine Hills exhibits a Middle Pleistocene landslide (Ueki, 2001). This indicates that the Omine Hills had been uplifted till the Middle Pleistocene enough to induce a landslide event. This suggests that the EMB fault started to move in the EarlyMiddle Pleistocene, with a resultant vertical slip-rate of approximately $3.0 \mathrm{~m} / \mathrm{kyr}$ since the Middle Pleistocene.

\section{Discussion}

Based on compilation from the available geomorphological and paleo-seismological data, average slip-rates of 1.0 and $2.9 \mathrm{~m} / \mathrm{kyr}$ are inferred for the region between Hakuba 


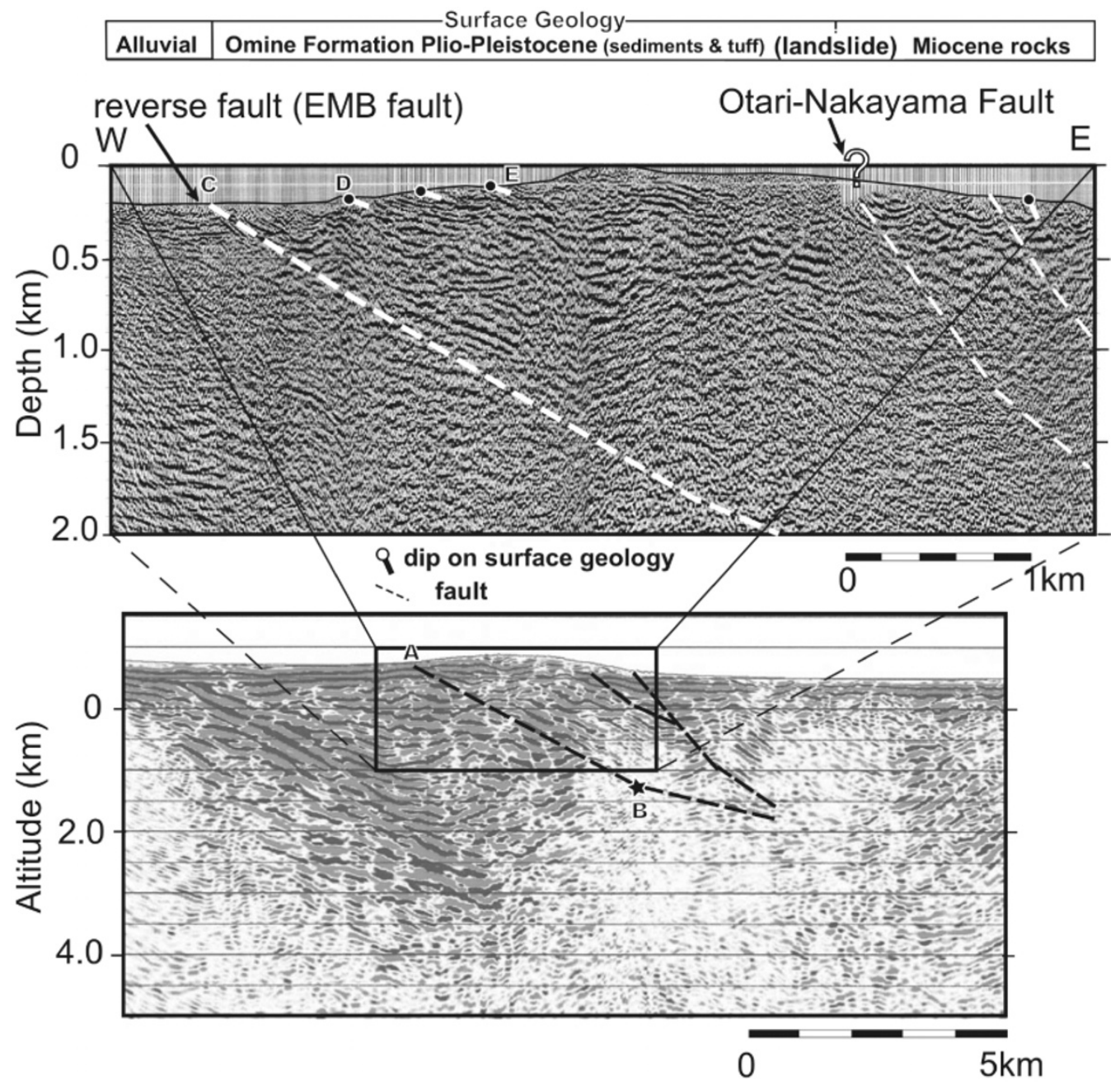

Fig. 7. Interpreted depth section of the shallow reflection profiling (Upper Figure) and the deep reflection profiling (Lower one; Sato et al., 2004) at Omachi. The relevant dips of the Omine Formation from the geological map (Kato and Sato, 1983) are marked on the seismic profile for reference.

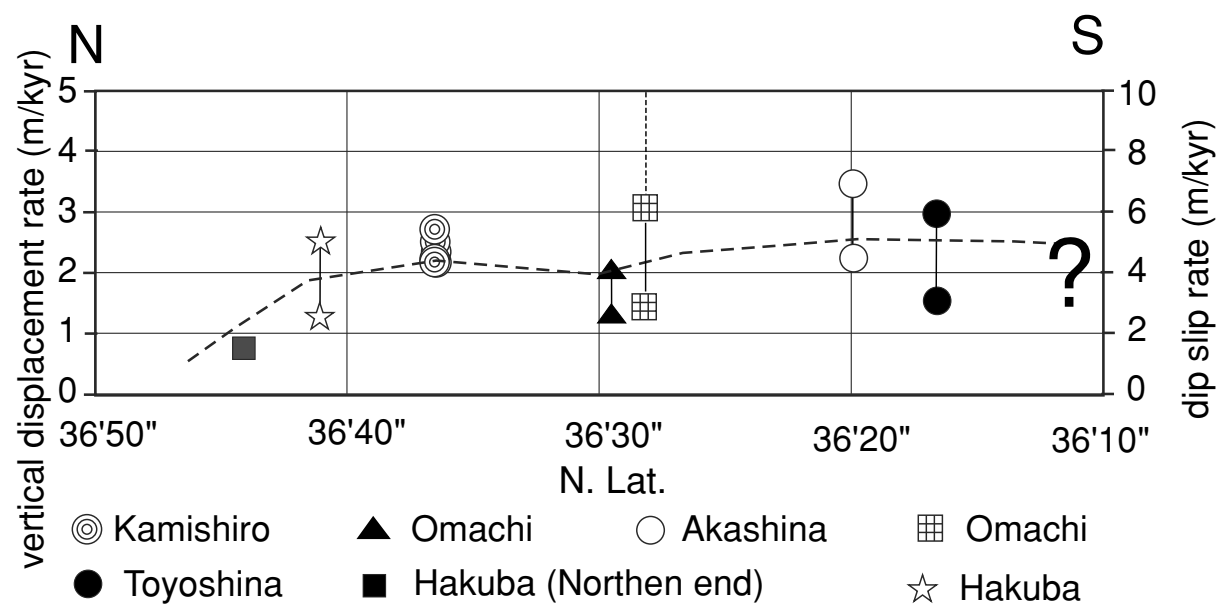

Fig. 8. Displacement profile along the northern ISTL active fault system.

and Toyoshina over the past $3 \mathrm{ka}$ (Table 1). We calculated as this dip angle of approximately $30^{\circ}$ for the northern ISTL active fault system. This dip angle is supported by the present profiles and is consistent with that of Sato et al. (2004) and Ikeda et al. (2004). In Toyoshina, three lower terraces can be identified along the active fault by
Matsuta (1999), and in Hakuba, one lower terrace can be identified according to Togo et al. (1996). It is likely that each of these terraces was uplifted and exposed during an earthquake, because each step of terraces is as low as $2-3$ $\mathrm{m}$ height. The slip-rate for the younger terraces can be determined from the offset of the geomorphic marker and the 


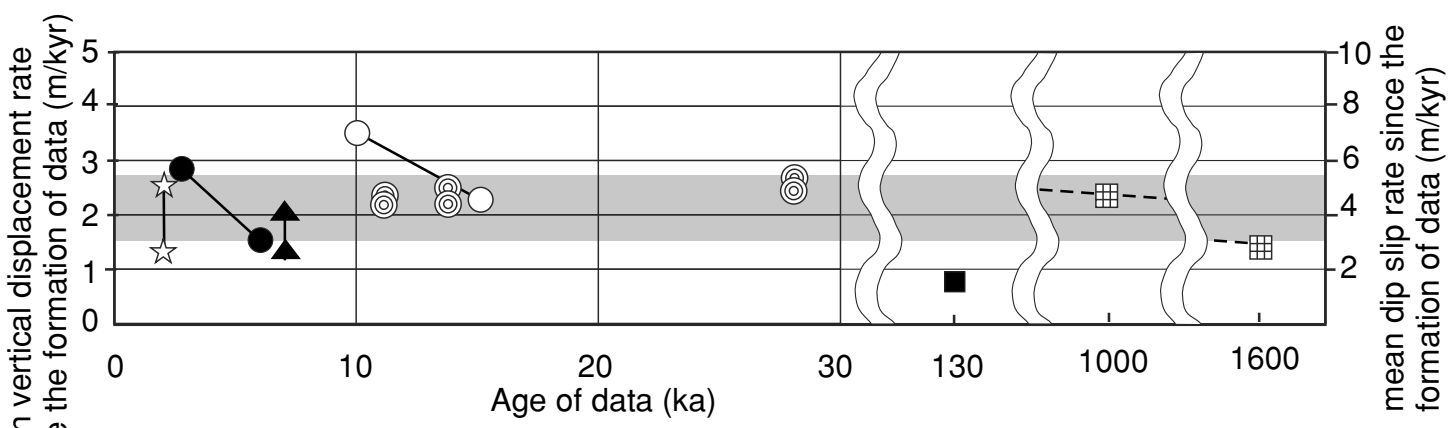

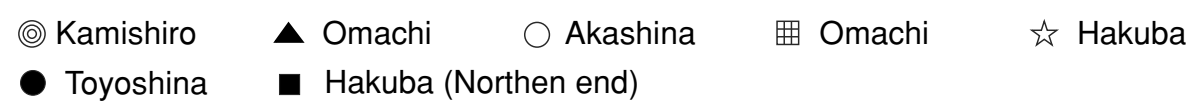

Fig. 9. The slip rates along the ISTL active fault system during the past $1.6 \mathrm{Ma}$.

Table 2. The compiled vertical and dip slip-rates along the northern part of the ISTL active fault system. Values with an asterisk are estimated values on the assumption that the dip angle of the fault is 30 degrees.

\begin{tabular}{|c|c|c|c|c|c|c|}
\hline Location & $\begin{array}{c}\text { Displace } \\
\text { ment (m) } \\
\text { V:vertical } \\
\text { D:Dip } \\
\end{array}$ & $\begin{array}{c}\text { Sedimentary } \\
\text { age (ka) }\end{array}$ & $\begin{array}{c}\text { Recurrence } \\
\text { interval (ka) } \\
\text { (a number } \\
\text { of event) }\end{array}$ & $\begin{array}{c}\text { Vertical } \\
\text { slip rate } \\
\text { (m/ka) }\end{array}$ & $\begin{array}{l}\text { Dip slip } \\
\text { rate (m/ka) }\end{array}$ & Reference \\
\hline Hakuba & $100 \mathrm{~V}$ & $>130$ & & 0.76 & 1.52 * & Koaze et al. (1974) \\
\hline \multirow[t]{2}{*}{ Hakuba } & \multirow[t]{2}{*}{$2-3 v$} & \multirow[t]{2}{*}{2} & $1.2-1.5$ (one) & $1.3-2.5$ & $2.6-5^{*}$ & \multirow[t]{2}{*}{ Togo et al. (1996) } \\
\hline & & & 2 (one) & $1-1.5$ & $2-3^{*}$ & \\
\hline \multirow[t]{4}{*}{ Kamishiro } & $<66 \mathrm{~V}$ & 28 & & $<2.4$ & $<4.8$ & Matsuta (2001) \\
\hline & $<73-75 \mathrm{~V}$ & $<28$ & & $2.6-2.7$ & $5.2-5.4$ & Matsuta (2001) \\
\hline & $<30-34 \mathrm{~V}$ & 13.5 & & $<2.2-2.5$ & $<4.4-5.0$ & Matsuta (2001) \\
\hline & $<24-26 \mathrm{~V}$ & 11 & & $<2.2-2.4$ & $<4.4-4.8$ & Matsuta (2001) \\
\hline \multirow[t]{2}{*}{ Omachi } & \multirow[t]{2}{*}{$10-12$ V } & \multirow[t]{2}{*}{7} & $1.2-1.5(4-5)$ & $1.6-2.0$ & $3.2-4.0$ & \multirow[t]{2}{*}{ Okumura (2001) } \\
\hline & & & $2(3-4)$ & $1.3-2.0$ & $2.6-4.0$ & \\
\hline Omachi & $\begin{array}{l}>4700- \\
5000 \mathrm{D}\end{array}$ & -1600 & & $>1.4$ & $>2.9$ & Matsuta (2003) \\
\hline Akashina & $35 \mathrm{~V}$ & $1.0-1.5$ & & 2.3-3.5 & $4.6-7^{\star}$ & Oguchi (1990) \\
\hline \multirow[t]{2}{*}{ Toyoshina } & \multirow[t]{2}{*}{$10-10.5 \mathrm{~V}$} & & $1.2-1.5$ (three) & $2-2.9$ & $4.0-5.8^{*}$ & \multirow[t]{2}{*}{ Matsuta (1999) } \\
\hline & & & 2 (three) & $1.5-1.8$ & $3.0-3.6^{*}$ & \\
\hline
\end{tabular}

recurrence interval. Two different interpretations have been made for this recurrence interval, 1200-1500 yrs by Okumura (2001), and 2000 yrs by the Headquarters for Earthquake Research Promotion (1996), respectively and the two corresponding slip-rates are listed in Table 2.

On the displacement profile along the northern ISTL active fault system, we can find the displacement tapers on the northern edge (Fig. 8). According to Togo et al. (1996), there is no evidence showing Late Quaternary faulting at the northern end of the ISTL active fault system. The average slip-rate tends to decrease toward the northern end.

Figure 9 shows the slip-rate change the ISTL active fault system based on the present analysis. The northern ISTL exhibits dip-slip-rate of at least $2.9 \mathrm{~m} / \mathrm{kyr}$, with a constant average rate of 2.0 to $5.8 \mathrm{~m} / \mathrm{kyr}$ since the Early Quaternary.
The regional stress field estimated by the focal mechanism and the geodetic measurement is east and west compression. The northern part of the northern ISTL active fault system trends in NNE, being consistent with the regional stress field. In the southern part of the northern active fault system, however, the strike of the fault trace is not consistent with the regional stress field. It is likely that the fault has some left-lateral slip and the net slip-rate might be larger than the dip-slip-rate which we estimated.

Sagiya (2003) suggested based on geodetic and structural data that a blind fault not newly known in the ISTL active fault system moved by $1.1 \mathrm{~m}$ during the 1918 Omachi earthquakes $(\mathrm{Mw}=6.1$ and $\mathrm{Mw}=6.5)$. On the basis of the characteristic earthquake concept (Schwartz and Coppersmith, 1984), the recurrence interval is estimated by average slip- 
rates on the fault and the displacement per an earthquake to be several hundred years.

If the slip rate is constant along the ISTL active fault system, it seems that a lot of earthquakes should have occurred along the fault. In fact, there are no historical materials that show frequent occurrence of earthquake. According to Okumura (2001), the $10 \mathrm{~m}$ displacement on the fault zone was suggested that a few earthquakes occurred over the last 7000 years at the Omachi trench site. These facts indicate that a few earthquakes which ruptured the ISTL active fault system occurred in this area. In conclusion, the northern ISTL active fault system has been active since the middle Pleistocene, accompanied with the earthquakes that occurred every one or two thousand years with several meters offsets. There seem to be considerable validity in high imminent potential for a large earthquake on this fault system proposed by the Headquarters for Earthquake Research Promotion (1996).

\section{Conclusion}

Analysis of the ISTL active fault system based on seismic reflection profiles, geology, and tectonic geomorphology data revealed that the fault system underwent vertical separation of 1.0-2.8 m/kyr and dip-slip of 2.0-5.8 m/kyr during the Middle to Later Quaternary. A paleoseismological data and long-term slip-rate along the northern ISTL suggests that the northern ISTL has the ability to occur a large earthquake.

Acknowledgments. The seismic experiments undertaken in this study were supported by a Grant-in-Aid for Scientific Research (No. 11480019) from the Ministry of Education, Culture, Sports, Science and Technology of Japan (MEXT). The authors extend their gratitude to Toshifumi Imaizumi, Tsuyoshi Haraguchi, Shigeru Toda, Masami Togo, Eiji Kurashimo, Tomonori Kawamura, Sou Nohara, the members of our seismic crew, and the members of the research project "Slip and Flow Processes In and Below the Seismogenic Region" for helpful discussion and comments. The authors also thank David Okaya for discussion and English editing. The seismic experiments were performed as part of the research project mentioned above with the support of MEXT. Valuable and constructive comments by Dr. Fujimoto, Dr. Komatsubara and an anonymous referee allowed significant improvement of this paper.

\section{References}

Geological Survey of Japan (eds.), 1:1,000,000 Geological Map of Japan (3rd ed.), Geological Survey Japan, Tsukuba, 1992.

Headquarters for Earthquake Research Promotion, Report on the evaluation and survey results for Itoigawa-Shizuoka tectonic line active fault system (September 11, 1996), Headquarters for Earthquake Research Promotion, Prime Minster's Office [Currently available from: http://www.jishin.go.jp/main/], 1996 (in Japanese).

Ikeda, Y., T. Imaizumi, M. Togo, K. Hirakawa, T. Miyauchi, H. Sato (eds.), Atlas of Quaternary Thrust Faults in Japan, Univ. of Tokyo Press, Tokyo, 254 pp., 2002.

Ikeda, Y., T. Iwasaki, H. Sato, N. Matsuta, and T. Kozawa, Seismic reflection profiling across the Itoigawa-Shizuoka Tectonic Line at Matsumoto, Central Japan, Earth Planets Space, 56, this issue, 1317-1323, 2004.

Imaizumi, T., T. Haraguchi, K. Okumura, M. Togo, Y. Ikeda, H. Shimazaki, T. Miyauchi, Y. Takahiro, and K. Ishimaru, Slip-rates on the Kamishiro active fault along the northern part of the Itoigawa-Shizuoka Tectonic Line, detected by long geo-slicer and drilling, Active Fault Res., 16, 3543, 1997 (in Japanese with English Abstract).

Kashiwagi, S., Activity of the Kamishiro fault and disappearance of the Ko-Kamishiro-ko (paleo-Lake Kamishiro), northern Fossa Magna.
Abstract, Association of Japanese Geographers (Nihon Chirigakkai Yokoshu), 33, 6-7, 1988 (in Japanese).

Kato, H. and T. Sato, Geology of the Shinanoikeda District. Quardrangle Series, Scale 1:50000, Geol. Surv. Japan, 93 pp., 1983 (in Japanese with English Abstract)

Koaze, T., S. Sugihara, B. Shimizu, Y. Utsunomiya, S. Iwata, and S. Okazawa, Geomorphological investigation around Mt. Hakubadake, Sundai Shigaku, 35, 1-86, 1974 (in Japanese).

Machida, H. and F. Arai, Atlas of tephra in and around Japan, Univ. Tokyo Press, Tokyo, 276 pp., 1992 (in Japanese).

Machida, H., H. Yamazaki, F. Arai, and O. Fujiwara, Omine phroclastic flow deposits: A marker tephra for the study of evolution of the Japan Northern Alps, Jour. Geography, 106, 432-439, 1997 (in Japanese with English Abstract).

Matsuta, N., Tectonics along the southeastern rim of Matsumoto basin considered from seismic profiling and tectonic landform, Master thesis, Graduate School of Science, Univ. of Tokyo, Tokyo, 41 pp., 1999.

Matsuta, N., Y. Ikeda, T. Imaizumi, and H. Sato, Subsurface structure of and rate of net slip on the Kamishiro fault, northern part of the ItoigawaShizuoka Tectonic Line, central Japan, Active Fault Res., 20, 59-70, 2001 (in Japanese with English Abstract).

Matsuta, N., Y. Ikeda, and H. Sato, Structure and behavior of the ItoigawaShizuoka Tectonic Line, Central Japan, in Quaternary Time: partitioning of slip on an oblique-slip fault zone, Abstract, IUGG, A495, 2003.

McCalpin, J. P., Paleoseismology, in International Geophysics Series, edited by R. Dmowska and J. R. Holton, Academic Press, San Diego, 588 pp., 1996.

Nagahashi, Y., Y. Satoguchi, and S. Yoshikawa, Correlation and stratigraphic eruption age of the pyroclastic flow deposits and wide spread volcanic ashes intercalated in the Pliocene-Pleistocene strate, central Japan, Jour. Geol. Soci. of Japan, 106, 51-69, 2000 (in Japanese with English Abstract).

Oguchi, T., Vertical slip rates of active faults around the central part of the Matsumoto Basin, central Japan, Active Fault Res., 8, 15-21, 1990 (in Japanese).

Okumura, K., Paleoseismology of the Itoigawa-Shizuoka tectonic line in central Japan, Jour. Seismol., 5, 411-431, 2001.

Research group for active faults in Japan, Active Faults in Japan, revised edition. Univ. Tokyo Press, Tokyo, 437 pp., 1991 (in Japanese with English Abstract).

Sagiya, T., A New Fault Model for the 1918 Omachi Earthquake-Leveling Data Revision and Integrated Interpretation of Multi-disciplinary Data, Jour. Seismol. Soci. Japan, 56, 199-211, 2003 (in Japanese with English Abstract).

Sato, H., T. Iwasaki, S. Kawasaki, Y. Ikeda, N. Matsuta, T. Takeda, N. Hirata, and T. Kawanaka, Formation and Shortening Deformation of Back Arc Rift Basins revealed by Deep Seismic Profiling across the ItoigwaShizuoka Tectonic Line active fault system, Central Japan, Tectonophys., 388, 47-58, 2004.

Schwartz, D. P. and K. J. Coppersmith, Fault behavior and characteristic earthquakes: Example from the Wasatch and San Andreas fault zones, Journal of the Geophysical Research, 20, 5681-5698, 1984.

Shimokawa, K. and H. Yamazaki, Fault movement analyzed from deposits of lake old Kamishiro, Abstract, Association of Japanese Geographers (Nihon Chirigakkai Yokoshu) 17, 92-93, 1987 (in Japanese).

Shimokawa, K., K. Mizuno, T. Imura, K. Okumura, Y. Sugiyama, and H. Yamazaki, 1:100,000 Strip map of the Itoigawa-Shizuoka Tectonic Line active fault system. tectonic map series 11, Geol. Surv. Japan, 1995 (in Japanese).

Takeuchi, A. and K. Abe, Neotectonics and seismic activity of the northern Itoigawa-Shizuoka Tectonic Line, central Japan, Abstracts, Seismol. Soc. Japan, 1999, Fall Meeting, A81, 1999 (in Japanese with English Abstract).

Togo, M., Y. Ikeda, T. Imaizumi, and H. Sato, Fault morphology of both ends of the Kamishiro fault along the Itoigawa-Shizuoka Tectonic Line, Central Japan, Active Fault Res., 15, 9-16, 1996 (in Japanese with English Abstract).

Ueki, T., Active history of the Itoigawa-Shizuoka Tectonic Line since Early Pleistocene, based on paleomagnetic stratigraphy of sediments, CDROM of the abstracts 2001, Japan Earth and Planetary Science Joint Meeting, Qm-004, 2001.

N. Matsuta (e-mail: matsuta@eri.u-tokyo.ac.jp), Y. Ikeda, and H. Sato 